\title{
Present Status of Solid Waste Management at Babylon Governorate, Iraq
}

\author{
Ali Chabuk1, Nadhir Al-Ansari'1, Hussain Musa Hussain², Sven Knutsson', Roland Pusch1 \\ ${ }^{1}$ Department of Civil Environmental and Natural Resources Engineering, Lulea University of Technology, Lulea, \\ Sweden \\ ${ }^{2}$ Department of Geology, Faculty of Science, University of Kufa, Kufa, Iraq \\ Email: ali.chabuk@ltu.se, nadhir.alansari@ltu.se, humhudhy02@gmail.com, Sven.Knutsson@ltu.se, \\ drawrite.se@gmail.com
}

Received: Jun. $11^{\text {th }}, 2015$; accepted: Jul. $13^{\text {th }}, 2015$; published: Jul. $16^{\text {th }}, 2015$

Copyright (C) 2015 by authors and Scientific Research Publishing Inc.

This work is licensed under the Creative Commons Attribution International License (CC BY).

http://creativecommons.org/licenses/by/4.0/

c) (i) Open Access

\begin{abstract}
Babylon Governorate covers an area of $5315 \mathrm{~km}^{2}$ with a population that reaches about 1,974,490 inhabitants in the central part of Iraq. Iraq produced 31,000 tons/day solid waste in 2013. The Governorate of Babylon produces annual 483,221 tons of solid waste. Management of collection and disposal of waste in Babylon Governorate is done through open dumping of waste and poor collection process. These sites do not conform to the scientific and environmental criteria applied in the selection of landfill sites. To find out how much solid waste is expected in the future, two methods were used to calculate the population growth in Babylon Governorate to the year 2030. The results showed that the total waste in 2030 will be 761,104 tons and 943055 tons while the cumulated quantity of solid waste expected till 2030 was $12,494,521$ tons and 14,095,437 tons according to the first and second methods respectively.
\end{abstract}

Keywords

Babylon Governorate, Solid Waste Management, Waste Disposal Sites, Iraq

\section{Introduction}

The term solid waste is a broad term that includes the unwanted or useless solid materials produced from residential, industrial and commercial activities in a specific area. Solid waste can be classified according to its origin (domestic, industrial, commercial, institutional and construction); according to potential of hazard from it (toxic, non-toxic, radioactive, flammable, infectious, etc.); as well as according to solid waste contents (organic material, glass, metal, plastic paper, etc.) [1]. Some of the waste cannot be reutilized and parts of it are consi- 
dered hazardous to natural resources and the environment (industrial waste, in particular). Population growth and improvements in living standards lead to significant increases in solid waste production, making solid waste management one of the major issues that the world faces today [2].

The negative impacts effects of poor solid waste management are potentially most dangerous for those living in third world countries, which are currently home to $80 \%$ of the world's population [3] [4]. Improper solid waste management causes air, soil and water pollution and is often the result of a lack of financial resources. According to [3] approximately $10 \%$ of each person's productive life is lost as a result of waste related diseases in third world countries. This fact has led to an increasing awareness of solid waste hazards on an international level. Consequently, legislation and laws have been being developed since the mid-20th century (e.g. 1972, UN conference in Stockholm; 1992, Earth Summit in Rio de Janeiro; 2000) [5]. The general objectives of these measures are to ensure sustainable development and proper management of waste in order to minimize its effects on people and the environment [2].

Iraq, an Arab country with a population exceeding 32 million inhabitants, is experiencing rapid economic growth. This, together with a growing population, increasing individual incomes and the instability generated by sectarian conflicts, has led to worsening solid waste management issues. Recurrent wars in Iraq have, also, created a lasting instability and as a result the country has become isolated and failed to keep pace with the continuous scientific progress of more developed countries. Waste management is considered one of the most complex issues that Iraq currently faces and there are many problems affecting the Iraqi waste management sector. Decades of war, sanctions, instability and mismanagement have all contributed to waste being disposed in irregular ways. Population growth has also led to more waste being produced, which has placed a tremendous strain on the infrastructure for waste handling (McCarthy, 2008 in [6]).

In 2013, Iraq produced 31,000 tons/day solid waste, and the capital of Iraq, Baghdad, produces more than 1.5 million tons of solid waste annually [7]. The governorate of Babylon produces an annual 483,221 tons of solid waste [8] [9]. There is an absence of modern, efficient waste handling and disposal infrastructure as well as a general lack of interest in/awareness of health and environmental issues. Unfortunately, the hallmarks of landfill sites in Iraq are groundwater contamination, surface water pollution, spontaneous fires, large-scale greenhouse gas emissions and increasing numbers of insects and rodents in/ round the area [7].

This study includes a comprehensive assessment of the reality of solid waste management in Babylon Governorate and the current locations of waste disposal sites in this governorate. Furthermore, future expectations of the quantities of solid waste were calculated.

\section{Babylon Governorate Background}

Babylon Governorate houses one of the most famous cities of the ancient world, the city of Babylon was built 4100 years ago, the city was the power center of an expansive and influential empire. The governorate is situated in the middle of Iraq about $100 \mathrm{~km}$ to the north of the Iraqi capital, Baghdad [10], between latitude $32^{\circ} 5^{\prime} 41^{\prime \prime} \mathrm{N}$ and $33^{\circ} 7^{\prime} 36^{\prime \prime} \mathrm{N}$, and longitude $44^{\circ} 2^{\prime} 43^{\prime \prime} \mathrm{E}$ and $45^{\circ} 12^{\prime} 11$ "E (Figure 1). It occupies a strategic location connecting the north and south governorates of Iraq together.

The governorate is characterized by relatively flat inclining land. The northern part of the governorate rises to approximately $60 \mathrm{~m}$ above sea level and falls to approximately $20 \mathrm{~m}$ over sea level in the southern part. This gradual decline is broken by a specific area of Al-Iskandariyah Nahiah, in the north of the governorate, which rises between 35 - $45 \mathrm{~m}$ above sea level. The land is fertile. The land is fertile because Shatt Al-Hillah River passes through most cities in Babylon Governorate. The river branches off from the Euphrates River at the town of Sadah Al-Hindiah in the north of governorate and forms an important part of the beautiful scenery that is a feature of this governorate [11].

Babylon Governorate has a population of about 1,974,490 inhabitants distributed throughout sixteen cities, as shown in the Figure 2 [12]. The governorate is divided administratively into five major cities, referred to as Qadhaa (the five Qadhaa are Al-Hillah (the political, financial and administrative capital of Babylon Governorate), Al-Hashimiyah, Al-Musayyab, Al-Mahawil and Al-Qasim). Sixteen smaller cities, called Nahiah, belong to these major cities (the sixteen Nahiah are Al-Hillah, Al-Kifil, Abi-Ghraq, Al-Hashimiyah, Al-Shomaly, AlMedhatyah, Al-Musayiab, Al-Iskandariyah, Al-Sadah, Jurf Al-Sakhar, Al-Mahawil, Al-Neel, Al-Imam, AlMashroa, Al-Qasim, and Al-Talyaah). Babylon Governorate covers an area of $5315 \mathrm{~km}^{2}$, including cities of Babylon Governorate. The administrative units of Babylon Governorate and their area are shown in Figure 3 and Figure 4, according to [11]. 


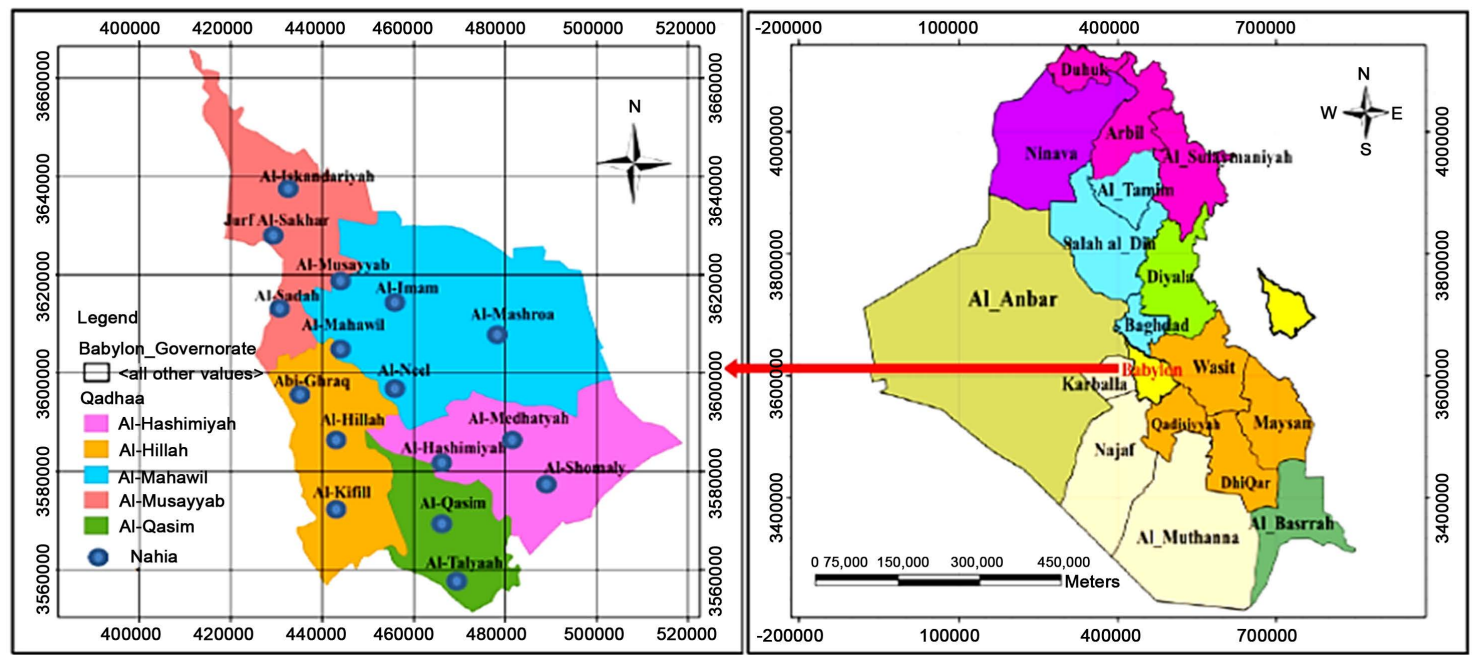

Figure 1. Map of Babylon Governorate.

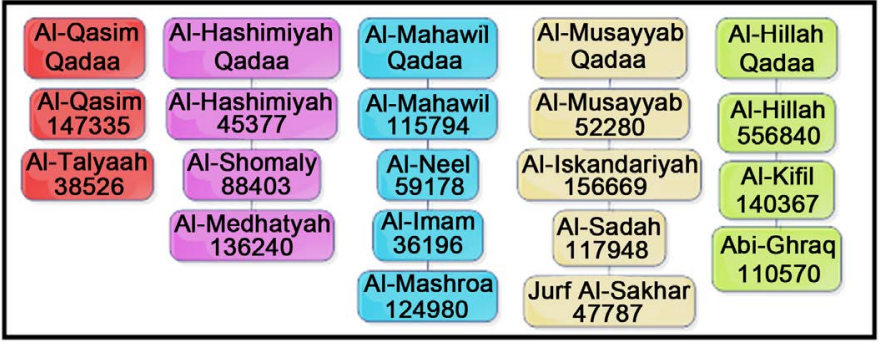

Figure 2. Administrative units of Babylon Governorate and its population/(1000) [12].

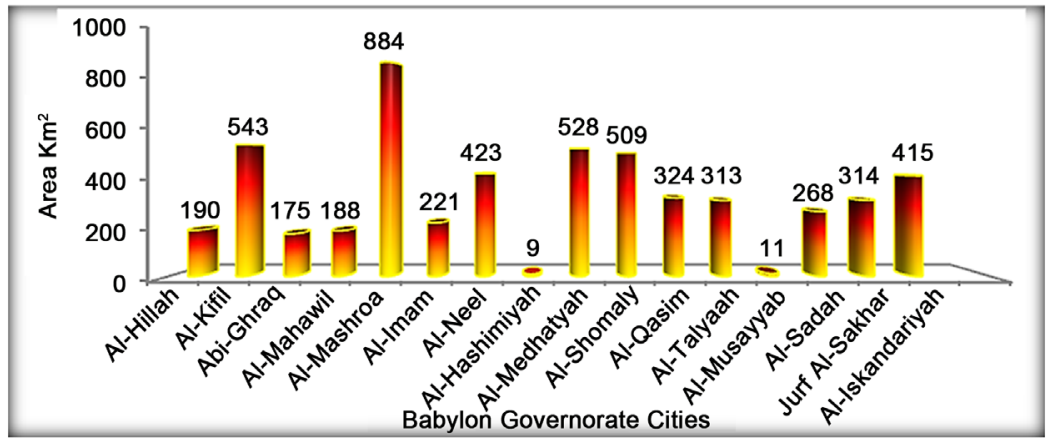

Figure 3. Cities area of Babylon Governorate [11].

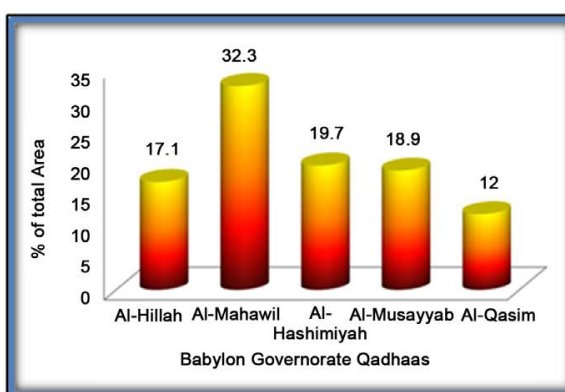

(a)

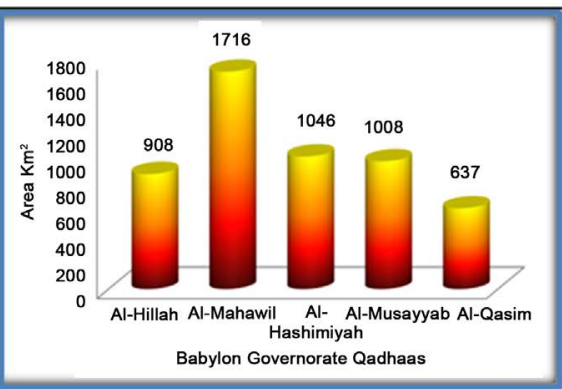

(b)

Figure 4. (a) Proportion of Qadhaas' area; (b) The total area for each Qadhaain Babylon Governorate [11]. 
Like 70\% of Iraq's surface area, the governorate is located in a desert climate fluctuate dramatically between day and night also with the changing seasons. The prevailing wind in the governorate comes from the North West and blows throughout the year. During the summer this wind blows an average of 4 days/month with an average wind speed of $3 \mathrm{~m} / \mathrm{s}$ and is considered moderate. Temperatures during the summer season can reach $45^{\circ} \mathrm{C}-50^{\circ} \mathrm{C}$ with 12 hours of sunlight/day and usually no precipitation. The winter is cold and rainy. Winds blow 3 days/month on average and the average wind speed is $7.4 \mathrm{~m} / \mathrm{s}$. There is 6.2 hours/day of sunlight with temperatures generally remaining above zero $0^{\circ} \mathrm{C}$ although on some nights they can fall below freezing. Precipitation falls at an average rate of 50 - $200 \mathrm{~mm} /$ month, which considered very low [10] [11].

\section{Present status of Solid Waste Management}

Solid waste is collected twice daily, once in the morning and once in the evening. It is collected manually by municipal workers in all districts of all cities in this governorate. After collection, the waste is put into various types of waste management vehicles, including waste compacters, large dumpers, tractors and small dumpers. The solid waste is then transferred to waste disposal sites or dumping sites which are spread throughout each city in Babylon Governorate according to available sites. The waste can be dealt with in different ways at different sites. Methods of handling the waste include burning and sometimes burying the remaining of them, as shown in Figure 5, and sometimes individuals, looking for potentially profitable waste components, sort the waste.

In general, it appears that the solid waste collection services in all cities of Babylon Governorate fail to handle the volumes generated by the population. The coverage of the waste collection services is estimated at $44 \%$ of the population. There are only two cities (Al-Hillah and Al-Hashimiyah) where a high level of service is achieved (90\%, 100\%) respectively [11]. It is clear that making solid waste collection services more efficient will be an important goal for future policy makers. Figure 6 shows the areas covered by municipal waste collection services in the cities of Babylon Governorate.

The municipal directorate of Al-Hillah is independent from the other municipal directorates. This is because the city of Al-Hillah has a high population density and is considered the political and economic center of Babylon Governorate. All other municipal directorates are connected administratively with the municipal directorate for Babylon. Through government of Babylon Governorate all municipal directorates are linked with the Ministry of Municipalities and Public Works.
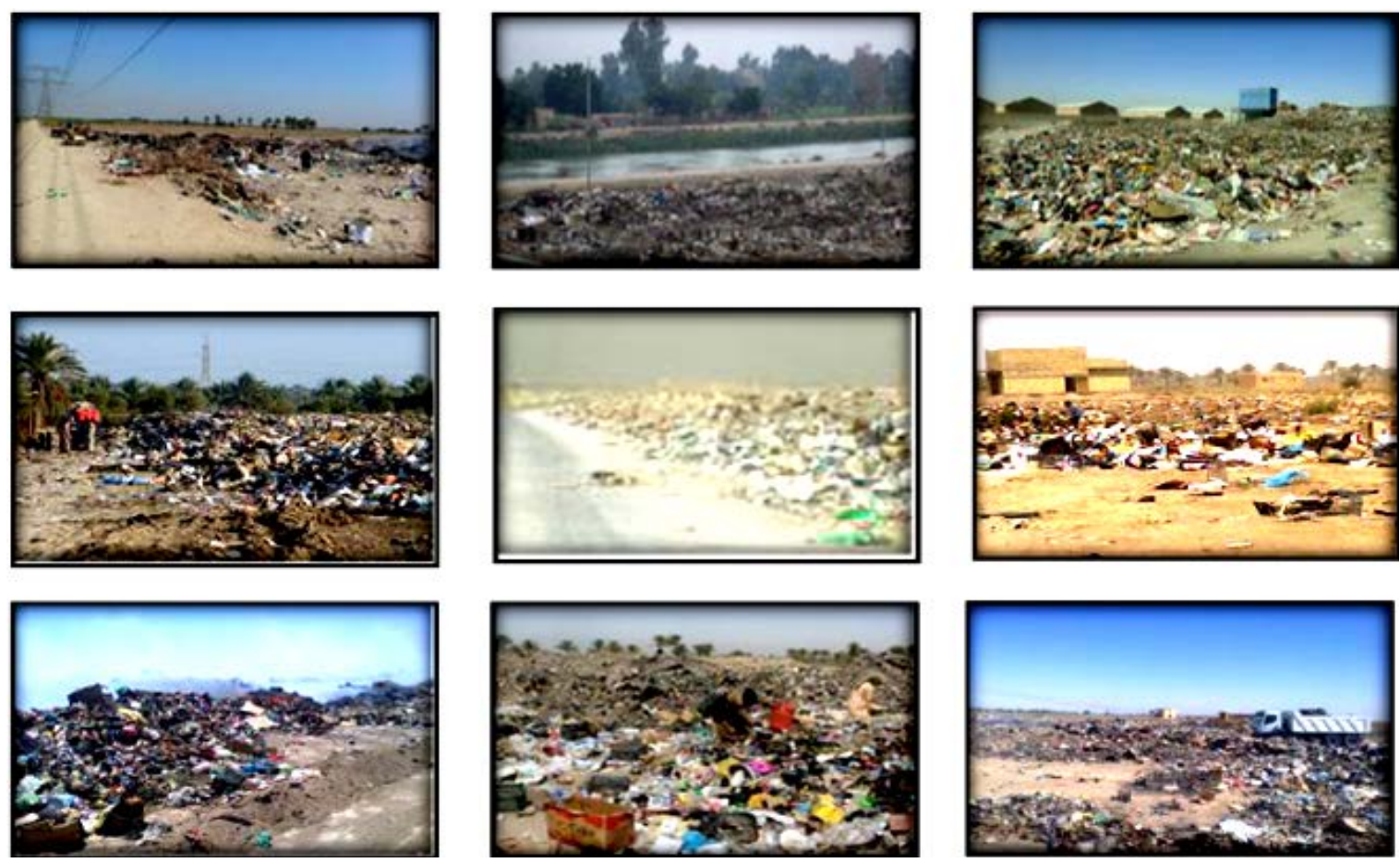

Figure 5. View of burning waste and manual waste selection at some dumping sites. 


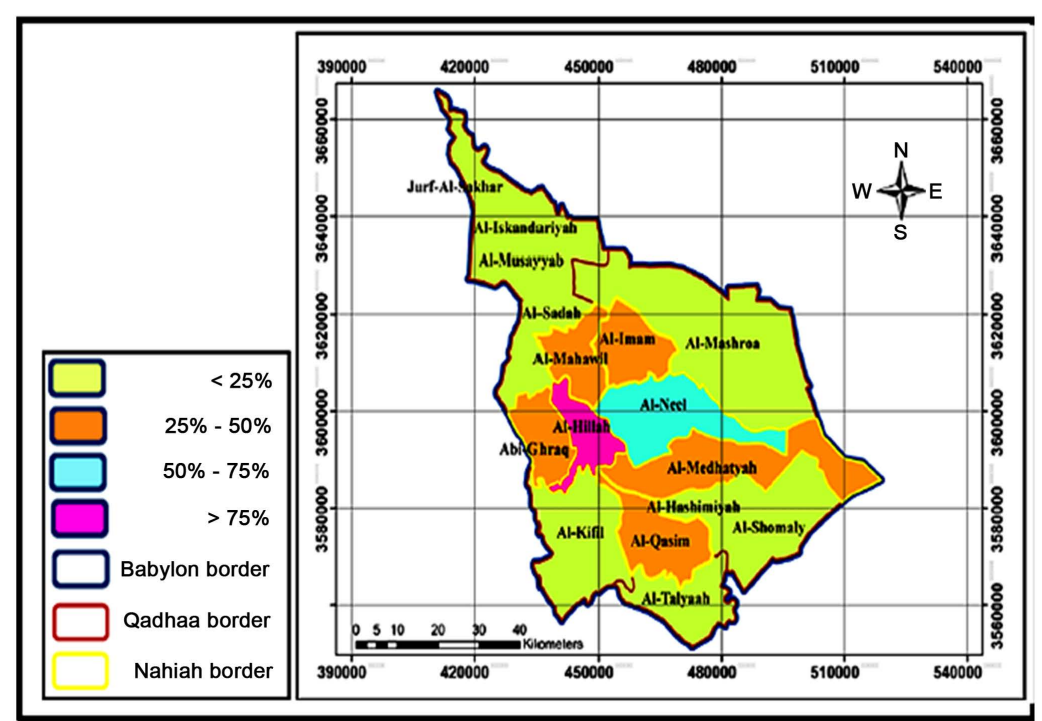

Figure 6. The population of areas which covered by the municipal service in Babylon Governorates' cities [11].

\subsection{Solid Waste Sources in Babylon Governorate}

Solid waste in Babylon Governorate can be categorized in the following way according to source:

1. Household waste.

2. Commercial waste from shops and markets dispersed throughout the governorate.

3. Industrial waste, from the industrial companies found in many cities of the governorate and focused on designated industrial areas.

4. Waste from the treatment plant, located in the city of Al-Hillah.

5. Agricultural waste resulting from the extensive agricultural in Babylon Governorate.

6. Social waste from educational institutions such as schools, colleges, etc.

7. Waste from general services such as hotels, restaurants, coffee shops and casinos.

8. Other.

Solid waste components in Babylon Governorate are categorized according to [8], as shown in Figure 7.

\subsection{Staff of Solid Waste Collection in Babylon Governorate}

Each city in Babylon Governorate has its own municipal directorate. The main task of the municipal directorate is to provide public service to citizens of the governorate. Each municipal directorate consists of several departments, and one of these departments is the environmental department. This department is linked administratively directly with the manager of the directorate. The department of solid waste management, which oversees all processes related to solid waste collection in each city, falls under the environmental department of the municipal directorate.

The staff of the solid waste management department consists of engineers, technicians, administrators, drivers, and waste collection workers, as shown in Figure 8.

\subsection{Machinery and Equipment Used in Waste Collection Process}

The waste collection department in each municipality has access to various vehicles (as shown in the Table 1 and Figure 9) to assist in the process of collecting and transporting waste from city districts to waste disposal sites. These vehicles include waste compacters, small dumpers, large dumpers, tractors, and trucks.

In those cities that do not have a major waste disposal site, the waste vehicles contribute to the transfer of waste from a temporary dumping site to a major waste disposal sites site in another city.

Heavy machinery is used to modify waste piles at collection sites as well as to construct or clear roads leading to sites. Some municipal directorates do not have a sufficient vehicles/machinery and must rent the equipment needed. 


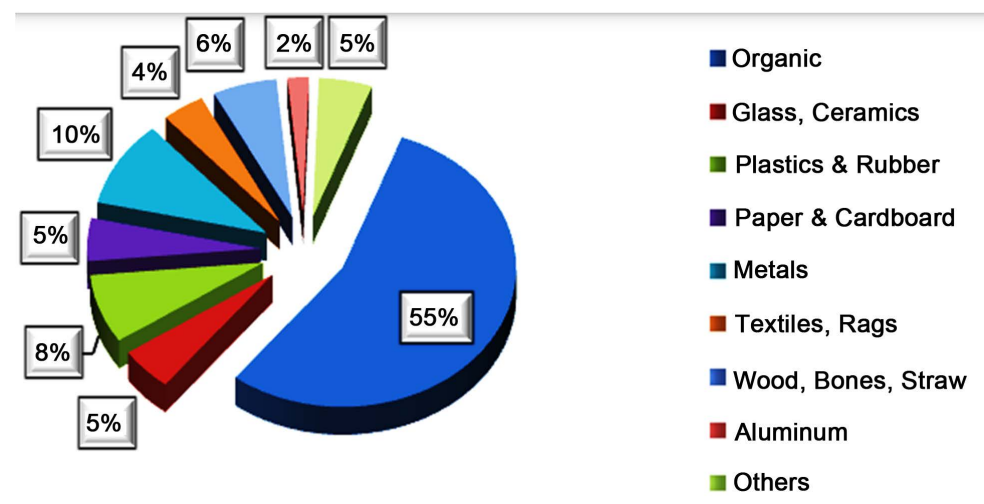

Figure 7. Composition of municipal solid waste in Babylon Governorate [8].

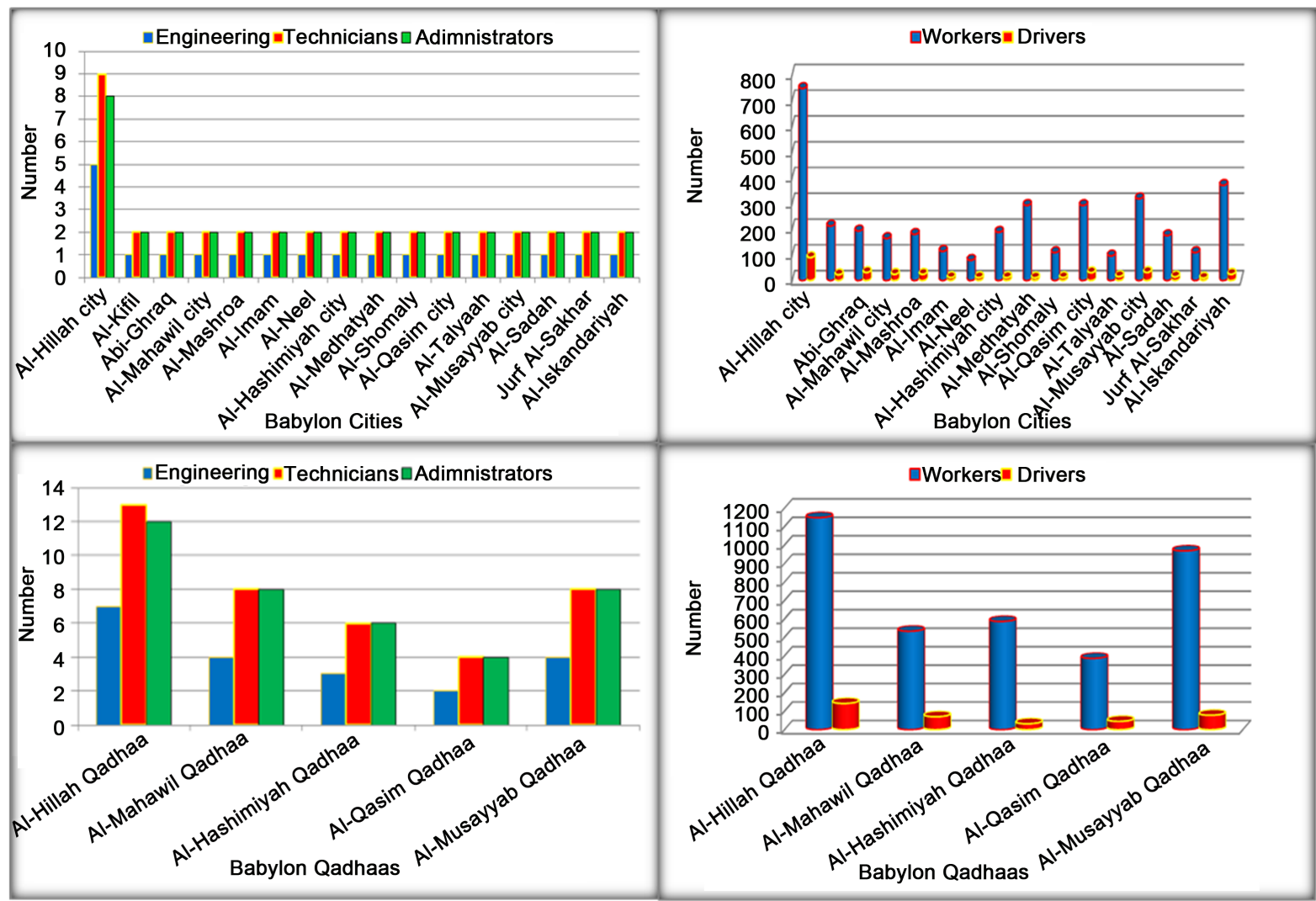

Figure 8. Staff of solid waste collection in Babylon Governorate’s cities also its Qadhaas [8] [9].

The municipal directorate is responsible for providing safety equipment for the staff of the waste collection department twice a year. This equipment includes gloves, boots and work clothes. Staffs are also supplied with the equipment necessary to carry out their daily work. The municipal directorate also provides the various containers for waste collection.

\subsection{Finance and Financial Management}

The budget that spent on waste collection process in Babylon Governorate in 2013 was 19,391,554,000 Iraqi dinars, equivalent to 15,894,716 US dollars depending on the 1220 exchange rate of the Iraqi dinar for each US dollar. This budget includes salaries of staff as well as the funds which spend on machineries maintenance (fuel, oils, spare parts, and others), also the safety equipment. It can be seen in Figure 10, that the budget of waste 

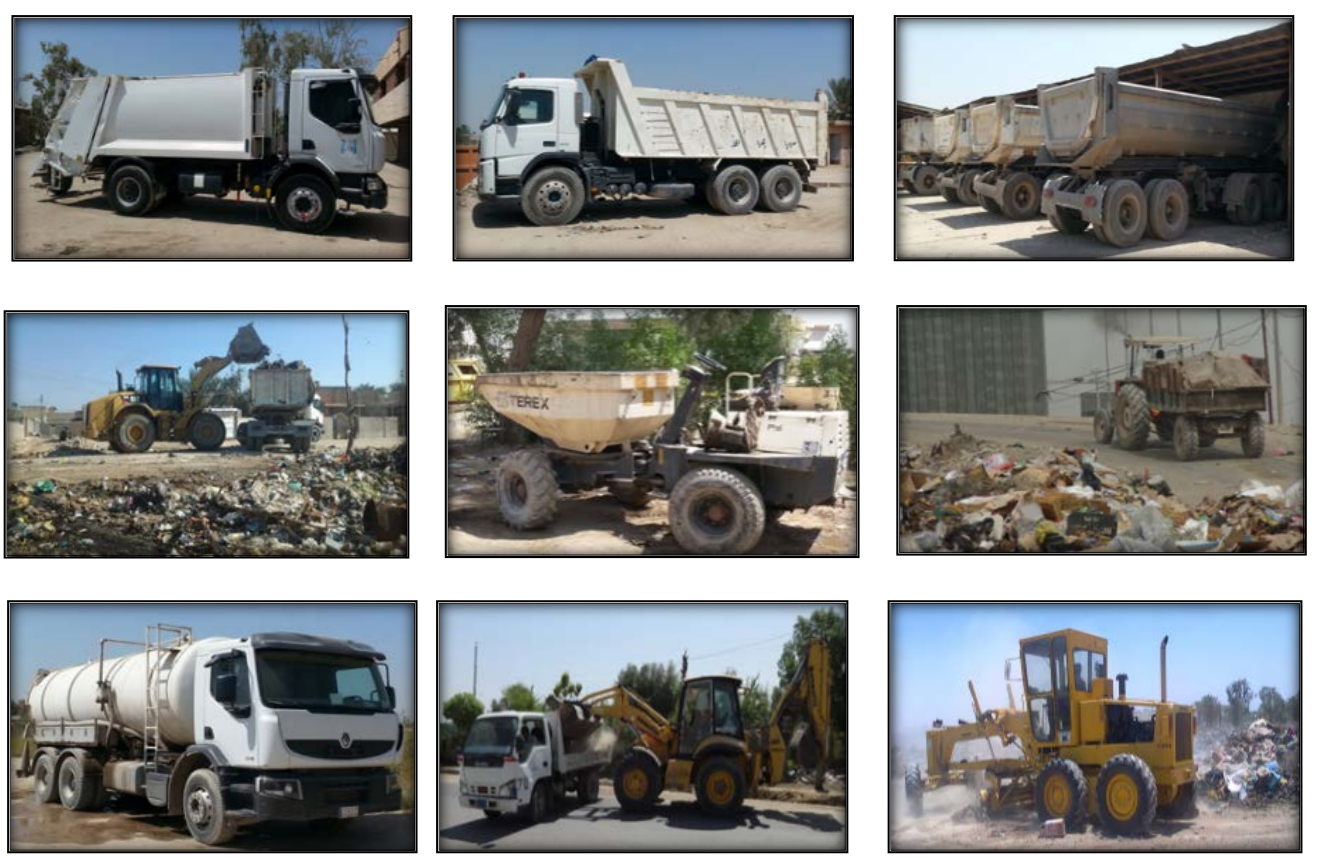

Figure 9. Types of machineries which are used in the process of collectionand transportation of solid waste in Babylon Governorate.

Table 1. Types of machineries used in collection and transportation of waste in Babylon Governorate [8] [9].

\begin{tabular}{|c|c|c|c|c|c|c|c|c|c|c|}
\hline Qadhaa & City & $\begin{array}{c}\text { Vehicles of } \\
\text { waste } \\
\text { compaction }\end{array}$ & Tractors & $\begin{array}{c}\text { Small } \\
\text { dumpers }\end{array}$ & Shuffles & $\begin{array}{c}\text { Big } \\
\text { dumpers }\end{array}$ & Trucks & Bulldozers & Tankers & $\begin{array}{c}\text { Trucks of } \\
\text { waste } \\
\text { compaction }\end{array}$ \\
\hline \multirow{3}{*}{ Al-Hillah } & Al-Hillah & 89 & 68 & 8 & 5 & 9 & 9 & 6 & 5 & 9 \\
\hline & Al-Kifil & 5 & 1 & 1 & 2 & 4 & - & 2 & 1 & - \\
\hline & Abi-Ghraq & 6 & 8 & - & 1 & 2 & - & - & 2 & - \\
\hline \multirow{4}{*}{ Al-Mahawil } & Al-Mahawil & 10 & 2 & - & 2 & 5 & - & 1 & 2 & 1 \\
\hline & Al-Mashroa & 7 & 6 & - & 1 & 2 & - & 1 & 2 & - \\
\hline & Al-Imam & 5 & 3 & - & 1 & 3 & - & 2 & 2 & - \\
\hline & Al-Neel & 4 & 3 & - & 1 & 3 & - & 1 & & - \\
\hline \multirow{3}{*}{ Al-Hashimiyah } & Al-Hashimiyah & 6 & 2 & 1 & 2 & 6 & - & 1 & 2 & - \\
\hline & Al-Medhatyah & 9 & 3 & 1 & 2 & 3 & - & 1 & 2 & 1 \\
\hline & Al-Shomaly & 4 & 5 & - & 1 & & - & 1 & 2 & - \\
\hline \multirow{2}{*}{ Al-Qasim } & Al-Qasim & 7 & 1 & 2 & 2 & 5 & - & 1 & 2 & 1 \\
\hline & Al-Talyaah & 7 & 1 & - & 1 & 3 & - & - & 2 & - \\
\hline \multirow{4}{*}{ Al-Musayyab } & Al-Musayyab & 9 & 8 & 14 & 1 & 2 & - & 1 & 1 & 1 \\
\hline & Al-Sadah & 6 & 2 & 1 & 2 & 2 & - & 1 & 2 & - \\
\hline & Jurf Al-Sakhar & 3 & 1 & - & 1 & - & - & - & 1 & - \\
\hline & Al-Iskandariyah & 11 & 10 & 1 & 1 & 6 & 1 & - & 2 & 1 \\
\hline
\end{tabular}




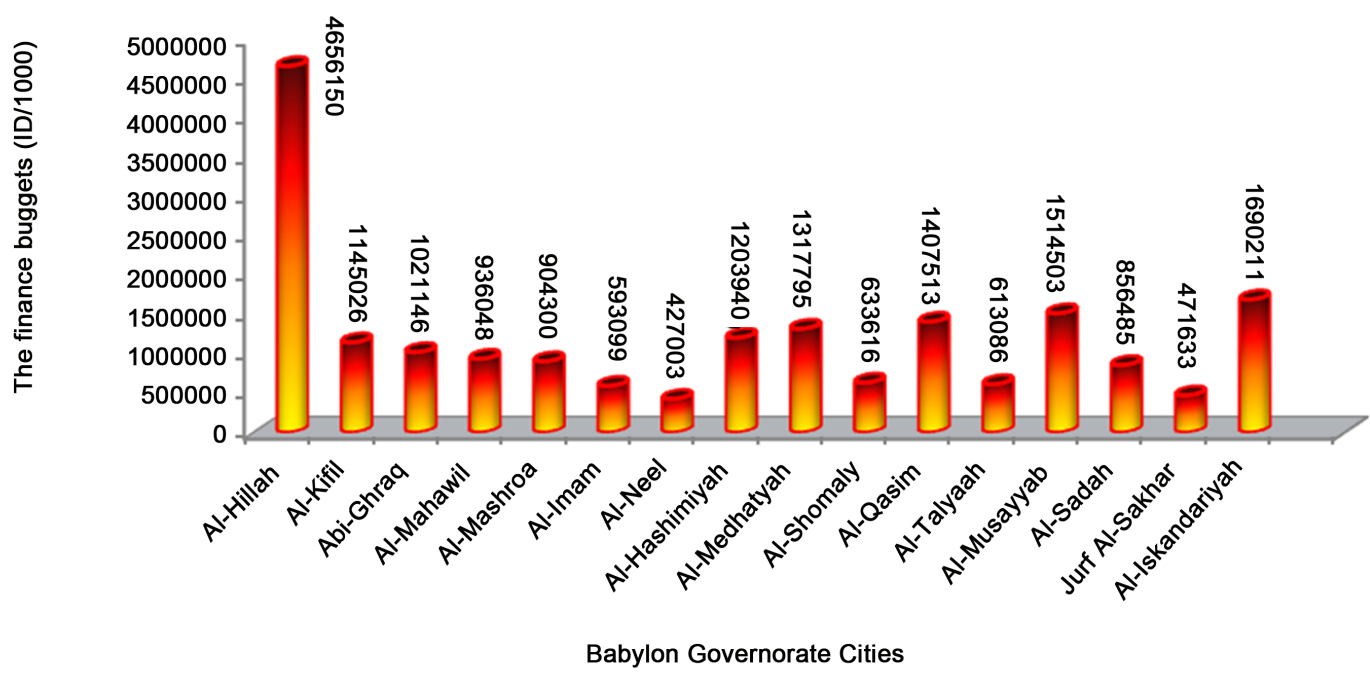

Figure 10. The finance budgets for solid waste collection process in Babylon Governorate in 2013 [8] [9].

collection process in 2013, that spent on Al-Hillah city through Al-Hillah municipality directorate was the highest among the other municipalities where was 6,822,322,000 Iraqi dinars equivalent to 5,592,067 US dollar [9], because of the vitality of this Qadhaa that considered the center political, economic, and commercial for Babylon Governorate, as well as it is characterized by presence of high population density.

As for Al-Hashimiyah Qadhaa, its budget for waste collection process in 2013 was 3,155,351,000 ID or 2,586,353\$, while the budget for Al-Musayyab Qadhaa was 4,532,832,000 ID or 3,715,436\$, whereas the budgets for Al-Mahawil Qadhaa and Al-Qasim Qadhaa were 2,860,450,000 ID or 2,344,631\$ and 2,020,599,000 ID or $1,656,229 \$$ respectively [8].

\subsection{Waste Disposal Sites in Babylon Governorate}

There are approximately sixteen waste disposal sites or dumping sites in Babylon Governorate. They are distributed throughout the cities of the Governorate, as shown in Figure 11 and Table 2. Most cities in the governorate have their own waste disposal sites and those that do not transport their waste to sites in neighboring cities. Waste is dealt with at the waste disposal sites by burning (on a daily basis) and burying what remains.

Most of these sites do not conform to the scientific and environmental criteria applied in the selection of landfill sites in more developed countries. Some of the sites do, however, meet certain criteria, e.g. an unexploited area at least $3-4 \mathrm{~km}$ from population centers, the presence of main and secondary roads that facilitate transporting waste to the site; a monitoring room to observe the process of depositing and modifying waste at the site, and the site is surrounded by a fence. These sites were not all approved by the responsible authorities, although some of them have received environmental approval. The sites in Babylon Governorate are under the management and monitoring of the municipal directorate in each city as well as the Babylon environmental directorate.

Waste disposal sites in the Al-Hillah Qadhaa are distributed as follows:

- Al-Hillah city contains four waste disposal sites. The first site is located outside the administrative borders of Al-Hillah city in Al-Neel Nahiah (Al-Mahawil Qadhaa) about $17 \mathrm{~km}$ from Al-Hillah city. This site is dedicated to receive the waste collected from Al-Hillah city, Abi-Ghraq Nahiah, and Al-Neel Nahiah. The second site is located in Al-Kifil Nahiah, which does belong administratively to Al-Hillah city. This site, located approximately $35 \mathrm{~km}$ from Al-Hillah city, has not been efficiently exploited by the Municipal Directorate. The third site is a temporary site and is used to collect waste from certain districts of Al-Hillah; this waste is then transferred to the Al-Neel waste disposal site. Al-Kifil Nahiah has one waste disposal site dedicated to collect waste from Nahiah. There is no waste disposal site in Abi-Ghraq Nahiah, which is completely dependent on the Al-Neel waste disposal site to collect its waste.

- In Al-Hashimiyah Qadhaa, the distance from site of waste disposal to the nearest agglomeration in Al-Hashimiyah Nahiah, Al-Medhatyah Nahiah, and Al-Shomaly Nahiah is approximately $5 \mathrm{~km}, 35 \mathrm{~km}$, and $10 \mathrm{~km}$ respectively. 


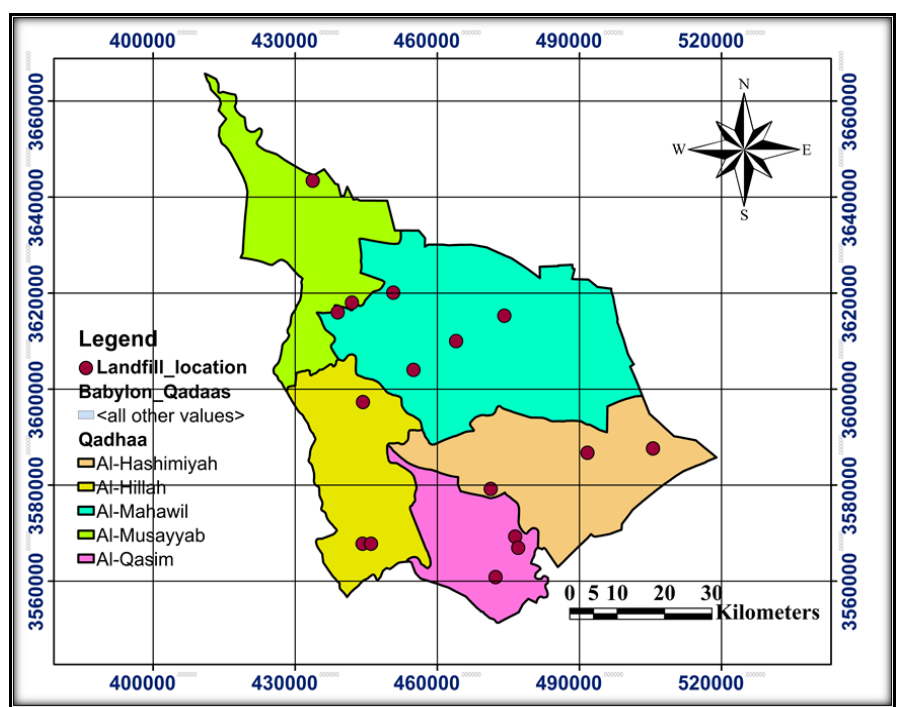

Figure 11. Locations of waste disposal sites in Babylon Governorate [8] [9].

Table 2. Waste disposal sites or dumping sites in Babylon Governorate [8] [9].

\begin{tabular}{|c|c|c|c|c|c|}
\hline Qadhaa & City & $\mathrm{X}$ & $\mathrm{Y}$ & $\begin{array}{c}\text { Area } \\
\text { (Acres) }\end{array}$ & Notes \\
\hline \multirow{5}{*}{$\begin{array}{l}\text { Al-Hillah } \\
\text { Qadhaa }\end{array}$} & \multirow{3}{*}{ Al-Hillah } & 455,000 & $3,604,000$ & 35 & $\begin{array}{l}\text { Al-Neel site, holds a permission from the directorate environment } \\
\text { in Babylon about the land only. }\end{array}$ \\
\hline & & 444,237 & $3,567,778$ & 15 & $\begin{array}{l}\text { Al-Kifil site, has not been getting a approvals from government au- } \\
\text { thorities and Babylon environmental directorate. }\end{array}$ \\
\hline & & 444,320 & $3,597,302$ & 2 & Al-Tajyah site, rejected because it exists among residential districts. \\
\hline & Al-Kifil & 446,036 & $3,567,778$ & 20 & $\begin{array}{l}\text { Al-Kifil site, has not been getting a approvals from government } \\
\text { authorities and Babylon environmental directorate. }\end{array}$ \\
\hline & Abi-Ghraq & 455,000 & $3,604,000$ & 35 & $\begin{array}{l}\text { There is not a site dedicated for this city, and its waste is transferred } \\
\text { directly to Al-Neel site. }\end{array}$ \\
\hline \multirow{4}{*}{$\begin{array}{l}\text { Al-Mahawil } \\
\text { Qadhaa }\end{array}$} & Al-Mahawil & 450,722 & $3,620,083$ & 25 & Rejected from Ministry of Water Resources. \\
\hline & Al-Mashroa & 474,174 & $3,615,265$ & 20 & Rejected from Ministry of Agriculture. \\
\hline & Al-Imam & 464,000 & $3,610,000$ & 50 & Rejected from authorities government in Babylon. \\
\hline & Al-Neel & 455,000 & $3,604,000$ & 35 & $\begin{array}{l}\text { Holds permission from the directorate environment in Babylon } \\
\text { about the land only. }\end{array}$ \\
\hline \multirow{3}{*}{$\begin{array}{l}\text { Al-Hashimiyah } \\
\text { Qadhaa }\end{array}$} & Al-Hashimiyah & 471,292 & $3,579,189$ & 54 & $\begin{array}{l}\text { The site rejected from Ministry of Municipalities and Public Works } \\
\text { and is dedicated to the Directorate of sewage in Al-Hashimiyah. }\end{array}$ \\
\hline & Al-Medhatyah & 491,725 & $3,586,727$ & 30 & $\begin{array}{l}\text { Holds permission from the directorate environment } \\
\text { in Babylon about the land only. }\end{array}$ \\
\hline & Al-Shomaly & 505,565 & $3,587,627$ & 30 & $\begin{array}{l}\text { Holds permission from the directorate environment in } \\
\text { Babylon about the land only. }\end{array}$ \\
\hline \multirow{3}{*}{$\begin{array}{l}\text { Al-Qasim } \\
\text { Qadhaa }\end{array}$} & Al-Qasim & 476,470 & $3,569,264$ & 35 & $\begin{array}{l}\text { Holds permission from the directorate environment in } \\
\text { Babylon about the land only. }\end{array}$ \\
\hline & \multirow[b]{2}{*}{ Al-Talyaah } & 472,322 & $3,560,834$ & 4 & Temporary site, irregular site. \\
\hline & & 477,105 & $3,566,939$ & 35 & $\begin{array}{l}\text { Holds permission from the directorate environment in } \\
\text { Babylon about the land only. }\end{array}$ \\
\hline \multirow{5}{*}{$\begin{array}{l}\text { Al-Musayyab } \\
\text { Qadhaa }\end{array}$} & Al-Musayyab & 433,724 & $3,643,401$ & 100 & $\begin{array}{l}\text { There is no a systematic site in this city, depends on } \\
\text { Al-Iskandariyah site. }\end{array}$ \\
\hline & \multirow{2}{*}{ Al-Sadah } & 439,000 & $3,616,000$ & 50 & rejected \\
\hline & & 442,000 & $3,618,000$ & 100 & rejected \\
\hline & Jurf Al-Sakhar & - & - & - & $\begin{array}{l}\text { There is not a site dedicated for this city, and its waste is transferred } \\
\text { directly to Al-Iskandariyah site. }\end{array}$ \\
\hline & Al-Iskandariyah & 433,724 & $3,643,401$ & 100 & $\begin{array}{l}\text { Holds permission from the directorate environment in Babylon } \\
\text { about the land only. }\end{array}$ \\
\hline
\end{tabular}


- Waste disposal sites that spread in the Al-Musayyab Qadhaa cities are considered irregular. In other words, these waste disposal sites are not conform to the scientific and environmental criteria applied in the selection of landfill sites. In Al-Musayyab Nahiah, the waste collection is done in irregular and unauthorized sites by Directorate Environment in Babylon Governorate, thus the waste of this Nahiah is transported to the waste disposal site in Al-Iskandariyah Nahiah.

- In Al-Sadah Nahiah, there are two locations for waste disposal, but irregular and environmentally unacceptable. The waste in this Nahiah often transported to the waste disposal site in Al-Iskandariyah Nahiah or it is burned in situ. There are no regular waste disposal sites in Jurf Al-Sakhar Nahiah. Municipality directorate of Jurf Al-Sakhar depends on bury or burn the remaining of them of its waste in situ or transporting waste direct to the waste disposal site in Al-Iskandariyah city.

- The site of waste disposal in Al-Iskandariyah Nahiah holds approval from the directorate environment in Babylon for some of the requirements, but this site is not conform to all the scientific and environmental criteria applied in the selection of landfill sites in more developed countries. This site receives the waste from the most cities of Qadhaa.

- Waste disposal sites in Al-Mahawil Nahiah, Al-Mashroa Nahiah, and Al-Imam Nahiah have not got the official approvals from government authorities because these sites intersect with many projects that follow to number of ministries in Iraq such as Ministry of Water Resources, Ministry of Agriculture and Ministry of Environment. The waste disposal sites or Nahiah in Al-Neel Nahiah receives waste from Al-Hillah city, AbiGhraq Nahiah and Al-Neel Nahiah. The waste is burned inside the site. This causes sometimes suffocation to population in Al-Neel Nahiah also to population in the cities that located around Al-Neel Nahiah; therefore the people constantly complain from existence this site there.

- In Al-Qasim Qadhaa the process of waste collection in Al-Qasim Nahiah is done through waste collecting from city districts, and then waste is put in a big temporary container that locates on the main street that connecting Babylon Governorate with the southern provinces. After that, the waste from the temporary location is transferred for waste disposal site in Al-Talyaah Nahiah. There is a new site located between Al-Qasim Nahiah and Al-Talyaah city, but this site needs the approvals from authorities responsible in order to be done working in it.

- Al-Talyaah Nahiah consists of two waste disposal sites, the first one is considered as a temporary site and uses to collect the waste, and this site is rejected from Babylon Environmental Directorate. The second site holds approval from Babylon Environmental Directorate, but this site is not conform to all the scientific and environmental criteria applied in the selection of landfill sites in more developed countries.

Table 3 shows the characteristics of each Qadhaa and Nahiah in Babylon Governorate. These characteristics include area of Babylon Governorate cities, area proportion of each city to total Babylon area, Population number of Babylon cities and proportion of urban and rural Population for each Nahiah and Qadhaa, number of waste disposal sites or dumping sites, solid waste quantities (ton), and generation rate of solid waste kg/(capita·day).

The waste generated rate in the some cities of Babylon Governorate was quite low; this due to the relatively low population compared with population of big cities, as well as rural population in these cities constitutes higher proportion compared with their urban population. Generally, rural populations are distributed on wide agriculture lands or on wide independent orchards, thus they depend on themselves in disposal of their waste, as well as those municipal services often do not reach to these areas.

\section{Expected Future Quantities of Solid Waste Generated}

Rates of solid waste production are subject to certain variables, such as population density, levels and types of economic activity, and the income level of the population [2]. In 2010 [13] established that the rate of solid waste generated in low-income countries was $0.9-0.4 \mathrm{~kg} /$ (capita·day), while the rates for middle and high-income countries were $0.5-1.1$ and $1.1-5.07 \mathrm{~kg} /$ (capita·day) respectively [2].

The structural plan for Babylon Governorate in 2009 [11] established that the rate of solid waste generated in Babylon Governorate in 2005 was $0.58 \mathrm{~kg} /$ (capita·day). This value is considered very low and is unsatisfactory, compared with the waste generation rates for both Iraq as a whole and for Baghdad (the capital of Iraq), which were 1.01 and $1.47 \mathrm{~kg} /$ (capita-day) respectively [11]. This rate is also low in comparison with the international standard value of $1.5 \mathrm{~kg} /$ (capita·day) [11]. The figures for the generation of solid waste per capita for Babylon 
Table 3. The characteristics of each Qadhaa and Nahiah in Babylon Governorate [8] [9] [12].

\begin{tabular}{|c|c|c|c|c|c|c|c|c|c|}
\hline Qadhaa & $\begin{array}{c}\text { City } \\
\text { (Nahiah) }\end{array}$ & $\begin{array}{l}\text { Area } \\
\left(\mathrm{km}^{2}\right)\end{array}$ & $\begin{array}{c}\text { \% of } \\
\text { Total } \\
\text { area }\end{array}$ & $\begin{array}{c}\text { Population } \\
\text { number } \\
2013\end{array}$ & $\begin{array}{c}\text { \% Urban } \\
\text { population } \\
2013\end{array}$ & $\begin{array}{c}\text { \% Rural } \\
\text { population } \\
2013\end{array}$ & $\begin{array}{c}\text { Locations } \\
\text { number }\end{array}$ & $\begin{array}{c}\text { Solid } \\
\text { waste } \\
\text { Ton (2013) }\end{array}$ & $\begin{array}{l}\text { Generation rate } \\
\text { of solid waste } \\
\text { (kg/capita/day) }\end{array}$ \\
\hline \multirow{4}{*}{$\begin{array}{l}\text { Al-Hillah } \\
\text { Qadhaa }\end{array}$} & Al-Hillah & 190 & 3.6 & 556,840 & 77.3 & 22.7 & 2 & 215,992 & 1.06 \\
\hline & Al-Kifil & 543 & 10.2 & 140,367 & 15.5 & 84.5 & 1 & 12,000 & 0.23 \\
\hline & Abi-Ghraq & 175 & 3.3 & 110,570 & 22.4 & 77.6 & - & 10,252 & 0.25 \\
\hline & Summation & 908 & 17.1 & 807,777 & 59 & 41 & 3 & 238,244 & 0.81 \\
\hline \multirow{5}{*}{$\begin{array}{l}\text { Al-Mahawil } \\
\text { Qadhaa }\end{array}$} & Al-Mahawil & 188 & 3.5 & 115,794 & 24.2 & 75.8 & 1 & 17,333 & 0.41 \\
\hline & Al-Mashroa & 884 & 16.6 & 124,980 & 29.6 & 70.4 & 1 & 20,690 & 0.45 \\
\hline & Al-Imam & 221 & 4.2 & 36,196 & 33.5 & 66.5 & 1 & 7968 & 0.60 \\
\hline & Al-Neel & 423 & 8.0 & 59,178 & 10.8 & 89.2 & 1 & 3386 & 0.16 \\
\hline & Summation & 1716 & 32.3 & 336,148 & 25 & 75 & 4 & 49,377 & 0.40 \\
\hline \multirow{4}{*}{$\begin{array}{l}\text { Al-Hashimiyah } \\
\text { Qadhaa }\end{array}$} & Al-Hashimiyah & 9 & 0.17 & 45,377 & 74.9 & 25.1 & 1 & 15,300 & 0.92 \\
\hline & Al-Medhatyah & 528 & 9.9 & 136,240 & 40.9 & 59.1 & 1 & 31,150 & 0.63 \\
\hline & Al-Shomaly & 509 & 9.6 & 88,403 & 19 & 81 & 1 & 5041 & 0.16 \\
\hline & Summation & 1046 & 19.7 & 270,020 & 38.3 & 61.7 & 3 & 51,491 & 0.52 \\
\hline \multirow{3}{*}{$\begin{array}{l}\text { Al-Qasim } \\
\text { Qadhaa }\end{array}$} & Al-Qasim & 324 & 6.1 & 147,335 & 51.7 & 48.3 & 1 & 36,033 & 0.67 \\
\hline & Al-Talyaah & 313 & 5.9 & 38,526 & 20.4 & 79.6 & 2 & 2880 & 0.20 \\
\hline & Summation & 637 & 12 & 185,861 & 45.2 & 45.8 & 3 & 38,913 & 0.57 \\
\hline \multirow{5}{*}{$\begin{array}{c}\text { Al-Musayyab } \\
\text { Qadhaa }\end{array}$} & Al-Musayyab & 11 & 0.21 & 52,280 & 100 & 0 & - & 39,400 & 2.06 \\
\hline & Al-Sadah & 268 & 5.04 & 117,948 & 26.8 & 73.2 & 2 & 14,396 & 0.33 \\
\hline & Jurf Al-Sakhar & 314 & 5.91 & 47,787 & 11.8 & 88.2 & - & 2400 & 0.14 \\
\hline & Al-Iskandariyah & 415 & 7.81 & 156,669 & 59.4 & 40.6 & 1 & 49,000 & 0.86 \\
\hline & Summation & 1008 & 18.97 & 374,684 & 48.8 & 51.2 & 3 & 105,196 & 0.77 \\
\hline
\end{tabular}

Governorate would position it as middle income in relation to the figures of the Department of Economic and Social Affairs of the UN in 2010 [2] [11].

The total population of Babylon Governorate in 2013 was 1,974,490 inhabitants [12] based on the population growth rate of 2.99\%, where the directorate of census in Babylon adopted the census of Iraq's Ministry of planning in 1997. According to [14], the annual population growth of Iraq is 2.5\% for years 2010-2014.

The quantity of solid waste generated in Babylon Governorate in 2013 was 483,211 ton [8] [9]. Generation rate of solid waste in 2013 was $0.67 \mathrm{~kg} /$ (capita·day) in this governorate depending on calculation methods which are explained below. The rate for each city in the governorate varies as a function of population density. Based on the information cited in the records of the Ministry of Planning, an attempt was made to calculate the future expected solid waste in Babylon for the year 2030. This was achieved using Equations (1)-(3) as follow:

Generation rate of solid waste (GRW) for year 2013 depending on quantity requirement of solid waste for specific year (Qs) and population of Babylon Governorate (P) for specific year (s) was calculated as:

$$
\mathrm{GRW}=(\mathrm{Qs}) /(\mathrm{P})
$$

where:

GRW: Generation rate of solid waste $\mathrm{kg} /($ capita·day).

Qs: Quantity of solid waste for one year (kg).

P: Population of Babylon Governorate for one year. 


$$
\text { GRWA }=\frac{483211 \times 1000}{1974490 \times 365}=0.67 \mathrm{~kg} /(\text { capita } \cdot \text { day }) \text { for year } 2013 .
$$

The average generation rate of solid waste for the last five years (GRWA) from 2009 to 2013, as showing below, was $0.64 \mathrm{~kg} /$ (capita·day) where it will be adopted to calculate the quantity of solid waste and accumulative solid waste for the year 2030 as:

$$
\text { GRWA }=\frac{432883 \times 1000}{1858626 \times 365}=0.64 \mathrm{~kg} /(\text { capita } \cdot \text { day }) \text { for last five years . }
$$

Equation (2) [15] [16] was used to calculate the population for each year from 2013 until 2030.

$$
\mathrm{P}_{\mathrm{t}}=\mathrm{P}_{\mathrm{o}}(1+\mathrm{r})^{\mathrm{t}}
$$

where:

$\mathrm{P}_{\mathrm{t}}$ : Future population at the end of period.

$\mathrm{P}_{\mathrm{o}}$ : Present population for year 2013.

R: The annual rate of growth (2.99\%).

t: Number of years.

$$
\begin{gathered}
\mathrm{P}_{2030}=\mathrm{P}_{2013} \times(1+\mathrm{r})^{\mathrm{t}} \\
\mathrm{P}_{2030}=1974490 \times(1+0.0299)^{17}=3258149 \text { capita . }
\end{gathered}
$$

Equation (3) was used to calculate the quantity of waste produced for year 2030. Using a waste generation rate of $0.64 \mathrm{~kg} / \mathrm{capita} / \mathrm{day}$ for the years 2009-2013 then:

$$
\text { Qs }(\text { for specific year })=\frac{\text { GRWA } \times \mathrm{P}_{2030} \times 365}{1000}
$$

Qs: Quantity of waste produced each year (ton).

So, $\operatorname{Qs}(2030)=\frac{0.64 \times 3258149 \times 365}{1000}=761104$ ton (for year 2030).

The cumulative quantity of solid waste generated by 2030 can be calculated, as shown in Equation (4):

For example the cumulative quantity of solid waste in 2030 Qs(c) is equal to the quantity of solid waste produced in 2030 Qs(ct) from Equation (3) plus the cumulative quantity of solid waste in 2029 Qs(nt - 1) for the year 2013. Then:

$$
\mathrm{Qs}(\mathrm{c})=\mathrm{Qs}(\mathrm{ct})+\mathrm{Qs}(\mathrm{ct}-1)
$$

where:

Qs(c): Cumulative quantity of solid waste for the specific year (ton).

Qs(ct): Quantity of solid waste for the specific year (ton).

Qs(ct-1): Cumulative quantity of solid waste for the last year before specific year (ton).

In order to calculate the cumulative solid waste generated by year 2030

$$
\begin{gathered}
\text { Qs }(2030)=\operatorname{Qs}(2030)+\operatorname{Qs}(2029) \\
\operatorname{Qs}(2030)=761104+11733417=12494521 \text { ton . }
\end{gathered}
$$

-Another attempt was made to calculate the expected rate of solid waste generated in Babylon governorate for the year 2030. This attempt was based on the fact that waste generation rates in 2005 and 2013 which were 0.58 and $0.67 \mathrm{~kg} /$ (capita·day) respectively [8] [9] [11] as follow:

$$
\mathrm{GRW}=(\mathrm{Qs}) /(\mathrm{P})
$$

where:

GRW: Generation rate of solid waste $\mathrm{kg} /($ capita·day).

Qs: Quantity of solid waste for one year (kg).

P: Population of city for one year. 


$$
\text { GRW }=\frac{483211 \times 1000}{1974490 \times 365}=0.67 \mathrm{~kg} /(\text { capita } \cdot \text { day }) \text { for year } 2013 .
$$

The population for each year from 2013 until 2030 was calculated as follows [15] [16]:

$$
\mathrm{P}_{\mathrm{t}}=\mathrm{P}_{\mathrm{o}}(1+\mathrm{r})^{\mathrm{t}}
$$

where:

$\mathrm{P}_{\mathrm{t}}$ : Future population at the end of period.

$\mathrm{P}_{0}$ : Present population for year 2013.

$\mathrm{R}$ : The annual rate of growth (2.99\%).

t: Number of years.

$$
\begin{gathered}
\mathrm{P}_{2030}=\mathrm{P}_{2013} \times(1+\mathrm{r})^{\mathrm{t}} \\
\mathrm{P}_{2030}=1974490 \times(1+0.0299)^{17}=3258149 \text { capita . }
\end{gathered}
$$

The rate of increment for waste generation rate of Babylon Governorate (RGI) based on values of waste generation rate in 2005 and 2013 is:

$$
\mathrm{RGI}=\frac{\mathrm{GRW}_{2013}-\mathrm{GRW}_{2005}}{\mathrm{n}}
$$

where:

RGI: Rate of increment for waste generation rate.

GRW2013: Generation rate of solid waste (kg/capita/day) of year 2013 [8] [9].

GRW2005: Generation rate of solid waste (kg/capita/day) of year 2005 [11].

n: Period (years).

$$
\mathrm{RGI}=\frac{0.67-0.58}{9}=0.01 \mathrm{~kg} /(\text { capita } \cdot \text { day }) .
$$

Equation (4) is used to calculate the generation rate of solid waste for year 2030 or specific year (GRSW) based on present generation rate of solid waste for year 2013 from Equation (1) and rate of increment for waste generation rate of each year from Equation (3), this equation similar to equation that used by [17].

$$
\text { GRSW }=\operatorname{GRW}_{(\text {year })}(1+\mathrm{RGI})^{\mathrm{n}}
$$

where:

GRSW: Generation rate of solid waste for each year.

GRW: Present generation rate of solid waste for year 2013 from Equation (1).

RGI: Rate of increment in waste generation per year.

n: Number of year.

$$
\operatorname{GRSW}_{(2030)}=\operatorname{GRW}_{(2013)}(1+0.01)^{17}
$$

$$
\operatorname{GRSW}_{(2030)}=0.67(1+0.01)^{17}=0.793 \mathrm{~kg} /(\text { capita } \cdot \text { day }) \text { generation rate of solid waste for year } 2030 .
$$

The quantity of waste (Qs) produced each year till year 2030 was based on generation rate of solid waste for specific year (GRSW) from equation 8 and future population for specific year $\left(\mathrm{P}_{\mathrm{t}}\right)$ from Equation (6) was calculated as:

$$
\text { Qs }(\text { for specific year })=\frac{\text { GRWA } \times \mathrm{P}_{2030} \times 365}{1000}
$$

Qs: Quantity of waste produced each year (ton).

So, $\mathrm{Qs}_{(2030)}=\frac{0.793 \times 3258149 \times 365}{1000}=943055$ ton $($ for year 2030$)$.

The cumulative quantity of solid waste generated by 2030 can be calculated, as shown in Equation (9). 
For example the cumulative quantity of solid waste in $2030 \mathrm{Qs}(\mathrm{c})$ is equal to the quantity of solid waste produced in 2013 Qs(ct) from equation 9 by adding the cumulative quantity of solid waste in 2029 Qs(nt - 1) to quantity of solid waste in 2030, accumulatively from year 2013 until 2030, the increment is done through adding the value of current year to past year until year 2030 as:

$$
\mathrm{Qs}(\mathrm{c})=\mathrm{Qs}(\mathrm{ct})+\mathrm{Qs}(\mathrm{ct}-1)
$$

where:

Qs(c): Cumulative quantity of solid waste for the specific year (ton).

Qs(ct): Quantity of solid waste for the specific year (ton).

Qs $(\mathrm{ct}-1)$ : Cumulative quantity of solid waste for the last year before specific year (ton).

-In order to calculate the cumulative solid waste generated by year 2030.

$$
\begin{gathered}
\mathrm{Qs}_{(2030)}=\mathrm{Qs}_{(2030)}+\mathrm{Qs}_{(2029)} \\
\mathrm{Qs}_{(2030)}=943055+13152382=14095437 \text { ton . }
\end{gathered}
$$

Figure 12 shows population of Babylon Governorate and its Qadhaas and cities for years 2009-2013 [12]. Quantities of Solid waste this governorate and its Qadhaas also its cities for years 2009-2013 show in Figure 13 (Ministry of Municipalities and Public Works, 2013b). Comparison of the results of the two methods (Figure 14) indicates that the first method gave slightly lower values $(12,494,521$ ton) while it was $(14,095,437)$ ton according to the second method. Figure 15 shows a comparison of the final solid waste generation rate in Babylon governorate and its Qadhaas for years 2013 and 2030.

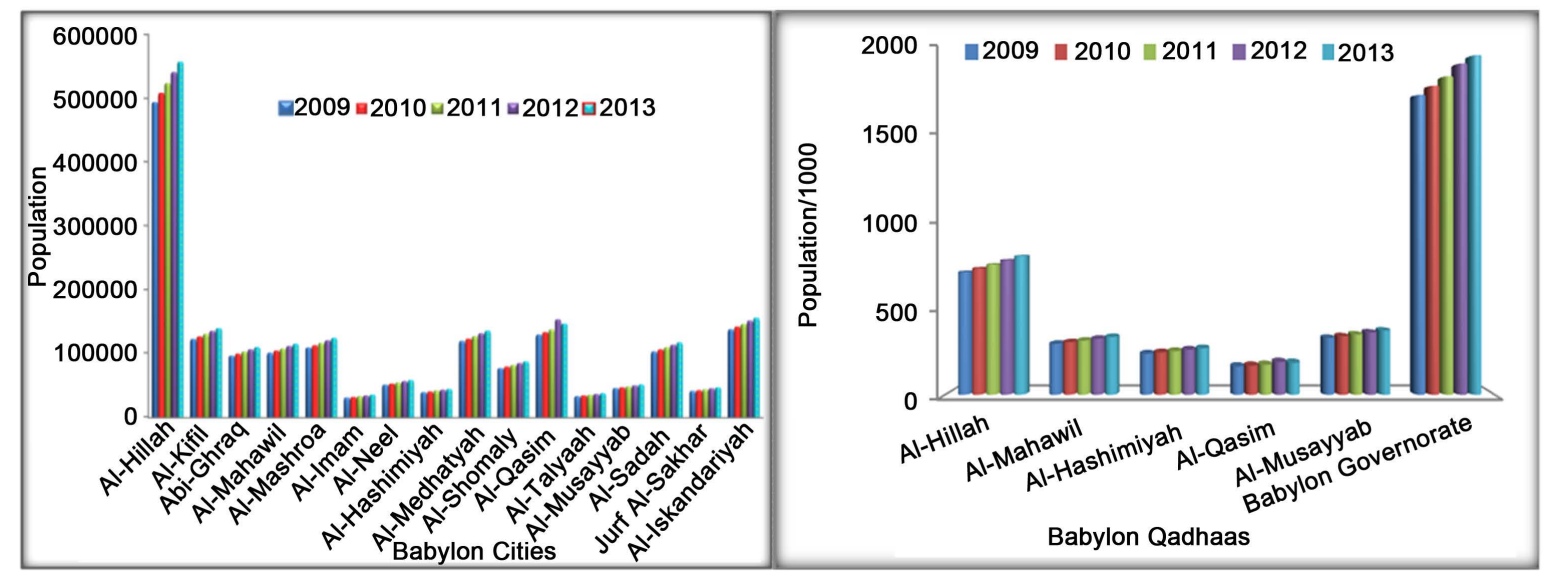

Figure 12. Population of Babylon Governorate and its Qadhaas also its cities for years 2009-2013 [12].

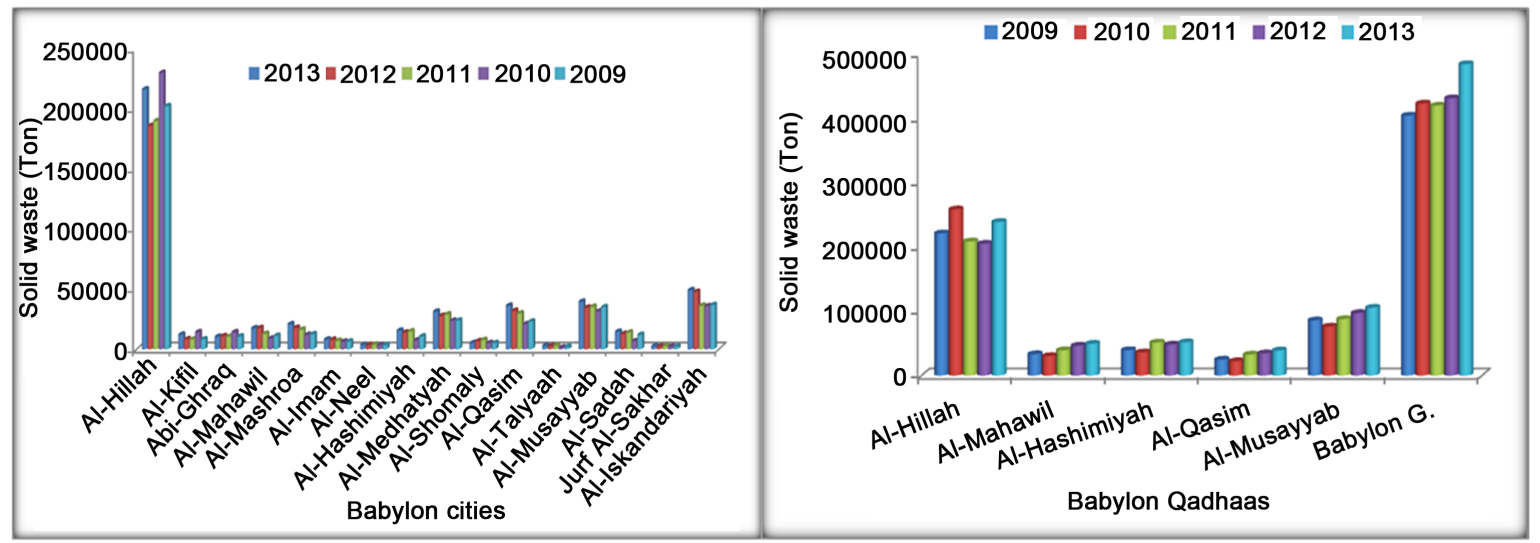

Figure 13. Solid waste quantity of Babylon Governorate and its Qadhaas also its citiesfor years 2009-2013 [8] [9]. 


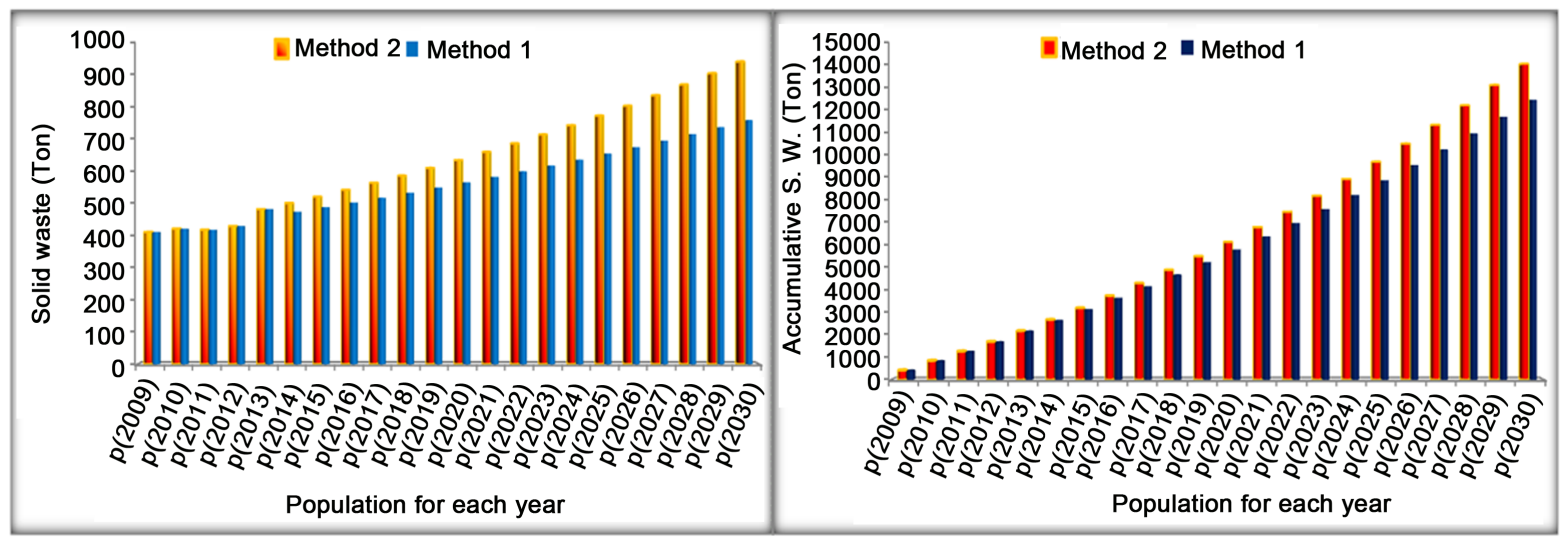

Figure 14. Solid waste and cumulative quantity of solid waste for each year in Babylon Governorate.

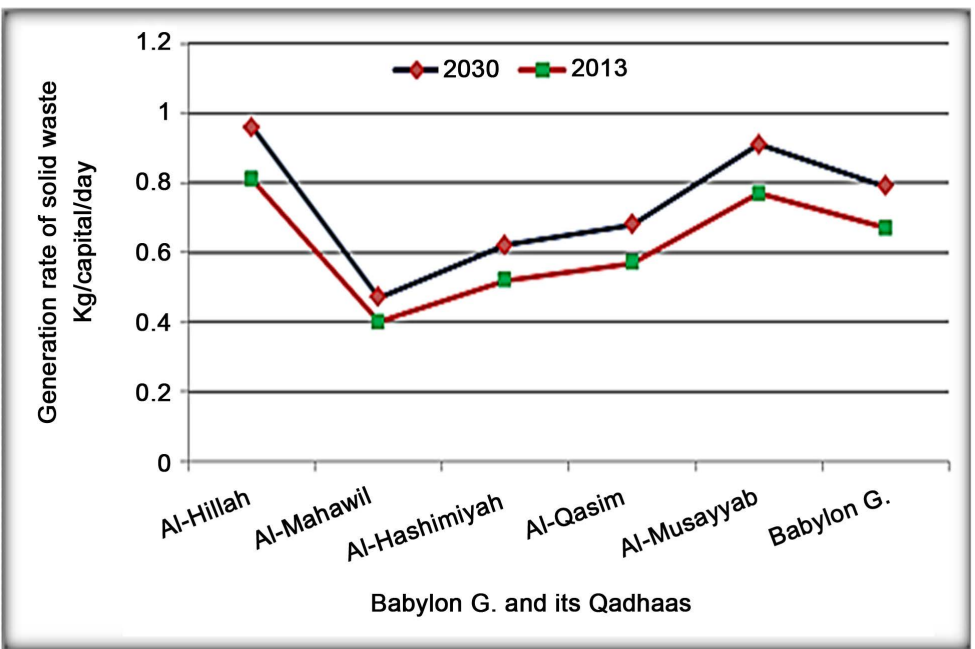

Figure 15. Generation rate of solid waste in Babylon Governorate and its Qadhaas for years 2013 and 2030.

\section{Conclusions}

Management of solid waste and disposal in Babylon Governorate at its present status does not fulfill the required international conditions. Waste disposal sites (sixteen sites) in this governorate are not conforming to the scientific and environmental criteria applied in the selection of landfill sites (waste disposal). Management of collection and disposal waste in Babylon Governorate is done through open dumping of waste and poor collection process. Open dumping of waste leads to many environmental problems including ground and surface water contamination, insect and rodent infestation, odors, disease, and others. Waste is disposed on daily bases in Babylon Governorate by burning. This causes sometimes suffocation to population in the cities located around them.

The value of generation rate of solid waste $0.67 \mathrm{~kg} /($ capita·day) is adopted in Babylon Governorate for 2013 with expected increment rate in generation rate of $0.1 \%$ per year. The values of generation rate in Babylon Qadhaa in 2013 were $(0.81,0.40,0.52,0.57$, and 0.77) kg/(capita·day) in (Al-Hillah, Al-Mahawil, Al-Hashimiyah, Al-Qasim, and Al-Musayyab) respectively. Comparison of generation rate of solid waste with other studies puts Babylon Governorate as a middle-income city.

Annual waste generated was 483,211 tons when inhabitants of Babylon Governorate in 2013 were 1,974,490. With the population growth rate of $2.99 \%$, the total population of this governorate will reach to 3,258,149; consequently waste generated will be 761,104 tons in 2030. The cumulative quantity of solid waste generated by 2030 starting from 2013 will be 12,494,521 and 14,095,437 tons in the first and second method respectively.

Municipal solid waste management by the Babylon Governorate authority needs to adopt an integrated opti- 
mization system for all process of solid waste management including segregation at source, timely and proper collection, routes of transportation, types of waste vehicles and selection sanitary landfill sites conforming to the scientific and environmental criteria applied in the selection of landfill sites (waste disposal) in more developed countries.

\section{References}

[1] Femi, F. and Oluwole, O. (2013) Management of Municipal Solid Waste. http://www.academia.edu/4254191/Management_of_Municipal_Solid_Waste

[2] Al-Ansari, N.A. (2013) Locating Landfills in Arid Environment. Journal of Earth Sciences \& Geotechnical Engineering, 3, 11-24.

[3] Pearce, D. and Walker, Ch. (1996) Sustainable Development. In: Baily, R., Ed., Water \& Environmental Management in Developing Countries, Amazon Company, UK.

[4] Jackson, B. (1996) International Institutions. In: Baily, R., Ed., Water \& Environmental Management in Developing Countries, Amazon Company, UK.

[5] Aldiab, S. (2000) The Gap between Planning and Execution of Environmental Policies in Jordan: A Case Study of Jordan Valley. M.A. Thesis, Al Al-Bayt University, Jordan.

[6] Rashid, S. (2011) Waste Management Policy in Iraq, Legal and Economic Instrument of Environmental Policy. Matriculation No. 3026257. https://www.academia.edu/1952326/Waste_Management

[7] Alnajjar, A.Y. (2013) Solid Waste Management Scenario in Iraq, Middle East, Solid Waste Management, EcoNENA. http://www.ecomena.org/tag/solid-waste-management-in-iraq

[8] Ministry of Municipalities and Public Works (2013a) Records of Directorate of Babylon Municipalities, Iraq, Babylon.

[9] Ministry of Municipalities and Public Works (2013b) Records of Directorate of Al-Hillah Municipality, Iraq, Babylon.

[10] Al Khalidy, K.S., Chabuk, A.J. and Kadhim, M.M. (2012) Measurement of Lead Pollution in the Air of Babylon Governorate, Iraq during Year 2010. World Academy of Science, Engineering and Technology, 6, 830-833.

[11] Ministry of Municipalities and Public Works, Iraq (2009) Structural Plan of Babylon Governorate.

[12] Ministry of Planning (2015) Records of Directorate of Census Babylon, Iraq.

[13] United Nation Department of Economic and Social Affairs (UNDESA) (2010) Trends in Solid Waste Management: Issues, Challenges and Opportunities. International Consultative Meeting on Expanding Waste Management Services in Developing Countries, Tokyo, 18-19 March 2010. http://81.47.175.201/flagship/attachments/UNEP Waste.pdf

[14] World Bank (2015) Population Growth (Annual \%). http://data.worldbank.org/indicator/SP.POP.GROW

[15] Jarabi, B. (2015) Population Projections, Population Studies \& Research Institute, University of Nairobi. Slide (11). http://unstats.un.org/unsd/demographic/meetings/wshops/morocco/2012/docs/s02.ppt

[16] United Nations (1952) Manual I: Methods for Estimating Total Population for Current Dates, United Nations Publications, Sales No. 52.XIII.5, Ch-5 (Estimates Derived by Extrapolation bf Census Results), 29. http://www.un.org/esa/population/techcoop/DemEst/manual1/chapter5.pdf

[17] Al-Rawi, M.S. and Al-Tayyar, T.A. (2012) Two Decades Comparison of Solid Waste Composition and Generation in Mosul City. Tikrit Journal of Engineering Science, 17, 25-43. 